\title{
The Literary Applications Of Biblical Phraseological Units
}

\author{
A. Grigoryan \\ Armenian State University of Economics \\ Corresponding author. E-mail: armgrig0407@mail.ru
}

Paper received 16.05.21; Accepted for publication 01.06.21.

\author{
https://doi.org/10.31174/SEND-HS2021-253IX45-04
}

\begin{abstract}
Linguistic expressions including phraseological units are the bearers of linguistic and stylistic meanings of many extralinguistic factors. Somatic phraseological units make up a large group in Modern English. One of the ways of representing somatic code is phraseological units with somatic element. The Bible and the great William Shakespeare left a huge phraseological heritage in English. The number of "biblical", or biblical phraseological turns is so great that it is rather difficult to list them. the main criteria of defining the presence of equivalents among English, Russian and Armenian somatic phraseological units are the general meaning, the structure and the lexical construction of the phraseological unit.
\end{abstract}

Keywords: phraseological unit, hereditary archetype, human body, cultural tradition, somatic code, concept, genetic prototype, biblical.

Linguistic expressions, including phraseological units are the bearers of linguistic and stylistic meanings of many extralinguistic factors. Linguistic studies as well as linguistic dictionaries based on those studies come to prove the above mentioned [1]. Language has been viewed as a mirror of social and cultural life by many linguists, cultural anthropologists and translators [2].

A phraseological unit can be defined as a nonmotivated word-group that cannot be freely formed in speech, but is reproduced as a ready-made unit. Phraseological units represent indirect and nominative means of designation and reflection of the logical thought processes, which, being expressed in certain language forms, gain a nationality-caused character. Phrases direct the reader-researcher towards their hereditary archetype, they also provide background knowledge about the history and culture of the given nation, the transmission of cultural traditions, as well as some tendencies of their modernization [3]. One of the ways of representing somatic code is phraseological units with somatic element. By means of such phraseological units and proverbs the language accumulates the empirical, spiritual and historical experience of the notion.

As A. Blume states [4], somatic phraseological units make up a large group in Modern English. The analysis of somatic phraseological units shows that most of them are formed by the following somatic lexemes: hand, leg I foot, head, eye, mouth, heart [5]. They account for about half of the studied phraseological units. The rest of the somatic lexemes are less frequently occurred. According to some calculations, 650 words were formed in Armenian only with the word "head", 350 with "eye", 260 with "mouth", and 180 with "face".

Mystical meanings as well as meanings specific to somatic phrases composed by the names of human body were revealed in the consciousness and speech of people. In general, for example, head appeared as a leader, (in the biblical sense - God, Christ), the heart - in the sense of emotion (in the biblical sense - the home of the Holy Spirit), the right hand as a symbol of activity, power, success, (in the inner sense - Jesus Christ), the left hand - in the sense of failure, misfortune (in the inner sense - Satan, Beelzebub). In any case, this is proved by both the biblical texts and the folklore derived from them, as well as literary and fiction works. When talking about the origins and archetypal examples of the latter, one should not dwell only on such initial manifestations, ignoring their further applications (in particular, their literary forms), as it allows the researcher to: 1) to reveal the archetypes of such applications 2) to point out the mythical, religious, historical-cultural factors, 3) to determine the character of any somatic phraseological unit in literature, related to the ideological, aesthetic and cognitive significance of the work, in general, to its entire global vertical context. For example, the abovementioned notions of "right" lu "left" ("right hand" li "left hand") have the following archetypal form in the Bible: 'But when you give alms, do not let your left hand know what your right hand is doing, so that your alms may be in secret; and your Father who sees in secret will reward you (Matthew 6:3-4). In the Jewish linguistic-cultural tradition, in addition to the meanings known to us (right-divine, left-satanic), there is also the meaning: right-south, left-north (= perception), so the above-mentioned example, according to the Jewish linguistic tradition, can be perceived and sounded like this: "Let your north not know what your south is doing" or just "Your north and your south have no news of each other". There are other variants also, both in oral (folklore) and written (literary) speech: "he doesn`t differ North and South", he has confused the North and the South ", etc. (in the Armenian linguistic and cultural tradition). H.Z. Ghazaryan, for example, gives the following version in Armenian-Russian-English: "The right hand should not know the work of the left." $\mathrm{У}$ него правая рука не выдает, что творит левая>> - "Not to let one's left hand know what one's right hand does; he carries fire in one hand and water in the other"'[6].

Usually, the study of the phraseological units, including the somatic phraseological ones, is based on their stylistic, denotative, significative and connotative meanings, as well as stylistic coloring, expressiveness, and imbued emotions, while when discussing the differences between ethnic and cultural peculiarities, the principles of Kunin's [7] phraseological identification or authentication should be considered, simultaneously adding to that principle that in order to prove identity, it is essential to show their archetypal patterns since their emergence and development. It's of vital importance to show not only the similarity of the phrases with its archetype, but also to prove the complete identification, to show the religious, mythological basis and reasons for 
the emergence of such phrases, that is, to justify the authentication not only with the similarity of the multilingual translations, but also referring to such matters and reasons, thus revealing not only interlinguistic correspondence, but also extralinguistic factors (beliefs, perceptions, cultural traditions) that have been the same for multilingual peoples, nationalities and nations.

Analysis of the translation of phraseological units reveals not only the meaning of the phrases, but also the code of their genetic prototype, as a result of which background knowledge is gained about the history, life, traditions, manners, that is, multifaceted culture of the given people. Through the comparison of "genetic prototype" and literary novelty, the "life" of the ancient phraseological units is detected in new socio-political situations from the prototype to the contemporary changes.

The Bible and the great William Shakespeare left a huge phraseological heritage in English. The number of "biblical", or biblical phraseological turns is so great that it is rather difficult to list them. It is quite relevant here to refer to those Shakespearean somatic phraseological units, which have their prehistoric, archetypal biblical "genetics". It is impossible to talk about Shakespeare without referring to his most important source, which is the Bible. Shakespearean somatic phraseological units, composed of the terms "hand", "blood", "head", have their own biblical archetypes, or more precisely, functions ascribed to them as well as their significations in spiritual sense.

Laertes. He is justly served;

It is a poison tempered by himself

Exchange forgiveness with me, noble Hamlet;

Mine and my father's death come not upon thee.

Nor thine on me!

[Act V, sc. II, p. 262]

Armenian linguists also have controversial opinions concerning the definition of a phraseological unit and the determination of its boundaries. S. Galsyan and A. Sukiasyan [8] observe sayings, proverbs, blessings and various tale expressions as a subtype of phraseological units, while P. Bediryan [9] and Kh. Badikian [9] are the supporters of the theory of narrow perception of phraseological units according to which only set phrases with a transferred meaning are called phraseologisms.

The Armenian translation is the renovation of the biblical sayings that served as a archetype for the original, in contrast to the Shakespearean original, which simply says that he (the king) deserved the poison made by himself, and as for Laertes and Hamlet, Laertes asks not to spill his and his father's death on Hamlet, and not to spill Hamlet's death on him. Armenian is the following.

Luiknun

hp цunăd unuguul, hapd th hp ătinpny ujn pnıjap huwndit:

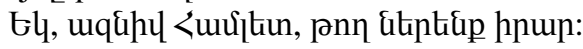

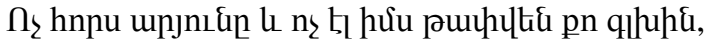

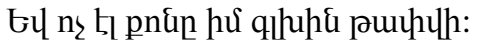

[Qnum V, untu. II, E2 176]

The animal that was sacrificed for the forgiveness of sins, in fact, took on the sins of the people when people put their hands on its head before slaughtering the bull. "He shall bring the bull to the door of the tent of meeting before the Lord, and lay his hand of the head of the bull, and kill the bull before the Lord. And the anointed priest shall take some of the blood of the bull and bring

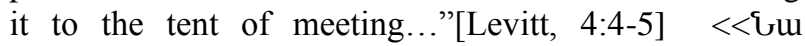

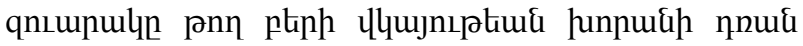
unun, Shpne unue, hp ătinpp pnn nâ qnıunulh

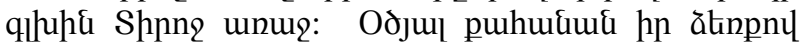

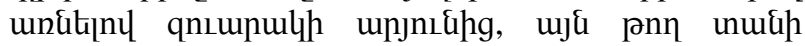

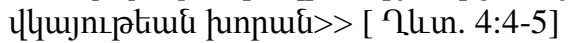

When speaking about the punishments of disobedience the word "suicide" is used for several times. According to the Scriptures, there are sins that call for the death for the personage - he is suicidal. In English it is said: "A man or a woman who is a medium or a wizard shall be put to death", they shall be upon them. [Levitihus 20:27]

The Armenian version says: < Gpt nplet,

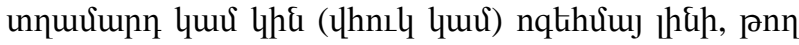

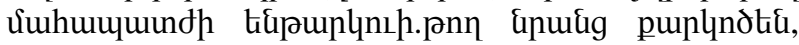

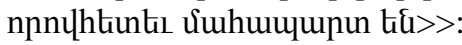

The English-Armenian comparison of the same dictum shows that "to commit suicide" means to shed blood on the head, or "let them have their blood on them" because the suicide was put to death by pelting with stones, with a broken head.

Therefore, we can be definitely say that Hovhannes Masehyan, the Armenian translator of Shakespeare's "Hamlet" has translated the words of dying Laertes from English into Armenia, based on the direct connection between the archetype referring to the biblical phrases: < unjnı\& puuhtip $>>$ (Shed sb's blood) पuर्u $<<$ unjnı\&p puihul quhuis>> (Call down curses (from heaven) upon $\mathrm{sb} / \mathrm{sb}$ 's head) luu $\ll$ hptikg unjnı\&口

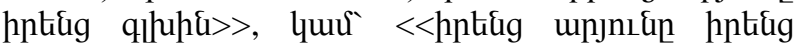
unu $>>$ (their blood shall be upon them):

Therefore, it is not fortuitous that blood is constantly shed in Shakespearean dramas: in one case it grants freedom from the sin of atonement and forgiveness, in the other case, that blood is shed as retribution. In this case, it is said that the person gains punishment instead of favor, and the shed blood "remains" on the guilty person. Horatio tells the English about the conspiracy against Hamlet.

And, in this upshot, purposes mistook

Fallen on the inventors' heads: all this can I

Truly deliver.

[Act V, Sc II, p 264]

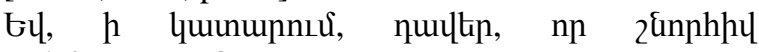
गjnıphर्याgnıрjuर,

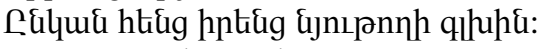

[Upup V, unku. II, 52 178]

There are many phrases like " spilling on one's head", "falling on one's head", both in the Bible and in Shakespeare's dramas. In such phrases, "head" is the key, and the role of the head in the anthropological structure. It is impossible to say when this somatic phrase emerged with all its similarities, but it should be mentioned that the concepts of the head are very old, dating back to the earliest periods of human history. It is already proved that these concepts are enshrined in the Bible and serve as archetypes.

Thus, the main criteria of defining the presence of equivalents among English, Russian and Armenian somatic phraseological units are the general meaning, 
the structure and the lexical construction of the phraseological unit. The somatic phraseological units of the English, Russian and Armenian languages possess a high interlingual equivalence that is explained by the fact that "body part" components are in the highfrequency vocabulary of these contrasted languages.

\section{ЛИТЕРАТУРА}

1. Великобритания. Лингвострановедческий словарь. М., 4. Блюм А., Семантические особенности соматической Русский язык, 1990

2. Hirch E. D. Cultural literacy: what every American needs to know. . N. Y., Vintage Books, 1988.,2. Howard G. The good English guide. (English usage in the 1990s). L., Macmillan, 1994., 3. Бархударов Л. С., Структура простого предложения современного английского языка. М., 1996, 4. Clark H.H. Using language. Cambridge, Cambridge University Press, 1996., 5. Hudson R. A. Sociolinguistics. Cambridge, Cambridge University Press, 1994.

3. Голдабина С.В., Федуленкова Т.Н. Роль античной и крестьянской культуры в изучении фразеологии современного английского языка // Культуроведческие аспекты росс. Образования. Теория, проблемы, опыт реализации. // Тезисы нац.-практич. Конф., Тюмень: ТГУ, 1996., 2. Федуленкова Т. Н., Некоторые аспекты герменевтики фразеологических единиц современного английского языка // Язык науки и бизнеса: материалы межжуз. науч. метод. Конфер., Тюмень, ТГНГУ, 1996. 3. Samovar L. A., porter R. E. (eds.) Intercultural communication: A reader. California, 1996 фразеологии, Москва, АСТ- пресс, 2000

5. H. Ghazaryan, Marmna maseri anvanumnerov hayerenruseren -angleren dardzvacqneri bararan, 2010:550-576

6. Кунин А. В., О стилистическом контексте во фразеологическом ракурсе. Сб. Науч. трудов МГПИИЯ им М. Тореза. Вып. 103, М., 1976. 2. Берлизон С. Б., (стилистический аспект значение фразеологических единиц и методы его исследования) // Проблемы семасиологии и лингвостилистики. Рязань, 1975, вып. 2., 3. Гаврин с. Г., Проблемы функционирования и развития фразеологического фонда русского языка в связы с общими вопросамы теории фразеологии. //на материале фразеологии 2-й половины 19 века и 20 века. /Дисс... докт. Филол. Наук. Л., 1975.

7. A. Suqiasyan, S. Galstyan, Hayoc lezvi dardzvacabanakan baararan, Erevan, p.616

8. P. Bediryan, Jamanakakic hayereni dardzvacabanutyun, Erevan, , 1973, p.213

9. Kh. Badikyan., Jamanakakic hayereni dardzvacajin miavorner, (Structural analysis), Yerevan, 1986

\section{REFERANCES}

1. Great Britain. Linguistic and Cultural Dictionary. M., Russian language, 1990, p.480

2. Hirch E. D. Cultural literacy: what every American needs to know. . N. Y., Vintage Books, 1988.,2. Howard G. The good English guide. (English usage in the 1990s). L., Macmillan, 1994., 3. Barkhudarov L.S., The structure of a simple sentence in modern English. M 1996, 4. Clark H.H. Using language. Cambridge, Cambridge University Press, 1996., 5.Hudson R. A. Sociolinguistics. Cambridge, Cambridge University Press, 1994.

3. Goldabina S.V., Fedulenkova T.N. The role of ancient and peasant culture in the study of phraseology of the modern English // Cultural aspects of Russia. Education. Theory, problems, realization experience. // Abstracts of the national-practical. Conf., Tyumen: TSU, 1996., 2. Fedulenkova TN, Some aspects of hermeneutics of phraseological units of the modern English // Language of science and business:

scientific. Method., Conf., Tyumen, TSOGU, 1996., 3. Samovar L. A., porter R. E. (eds.) Intercultural communication: A reader. California, 1996

4. A. Blume., Semantic features of somatic phraseology, Moscow, AST-press, 2000

5. H. Z. Ghazaryan; Armenian-English-Russian dictionary of somatic phrases. 2010, p.550-576

6. A. Kunin; On the stylistic context in a phraseological perspective., M., 1976. 2. Berlison SB, (the stylistic aspect of phraseological units and methods of its research) // Problems of semasiology and linguistic stylistics. Ryazan, 1975, no. 2., 3. Gavrin p. G., Problems of the functioning and development of the phraseological fund of Russian in connection with general issues of the theory of phraseology. // based on the phraseology of the 2nd half of the 19th century and the 20th century. / 1975. 